\title{
Plant growth promoting bacteria Bacillus subtilis promote growth and physiological parameters of Zingiber officinale Roscoe
}

\author{
D. Jabborova ${ }^{1,2^{*}}$, Y. Enakiev ${ }^{3}$, K. Sulaymanov ${ }^{1,4}$, D. Kadirova ${ }^{5}$, A. Ali $^{6} \&$ K. Annapurna ${ }^{2}$ \\ ${ }^{1}$ Institute of Genetics and PEB, Academy of Sciences of Uzbekistan \\ ${ }^{2}$ Division of Microbiology, ICAR-Indian Agricultural Research Institute, India \\ ${ }^{3}$ Agricultural Academy, “Nikola Pushkarov" Institute of Soil Science, Agrotechnology and Plant Protection, Sofia 1331, Bulgaria \\ ${ }^{4}$ Tashkent State Agrarian University, Uzbekistan \\ ${ }^{5}$ Termez State University, Termez, Uzbekistan \\ ${ }^{6}$ Department of Life Sciences, University of Mumbai, Vidyanagari, Santacruz (East), Mumbai 400 098, India \\ *Email: dilfuzajabborova@yahoo.com
}

\section{ARTICLE HISTORY}

Received: 15 October 2020

Accepted: 21 November 2020

Published: 01 January 2021

\section{KEYWORDS}

Plant

Bacterial inoculation

Plant height

Transpiration rate

Chlorophyll content

\section{ABSTRACT}

Ginger (Zingiber officinale Roscoe) is an important medicinal crop grown for its aromatic rhizome which is used as a spice, food, flavouring agent and medicine. It has been characterised for its hypoglycemic, hypotensive, antioxidant and antibiotic properties. This study was conducted to determine the impact of plant growth-promoting potential of bacterial strain Bacillus subtilis L2 on plant growth and physiological properties of ginger. The experiment was carried out in randomised block design with three replications in pot experiments. The plants were grown in greenhouse conditions for three months. The results showed that at 8 and 12 weeks after planting (WAP) bacterial inoculation increased plant height, leaf length, number of leaves per plant and leaf width. Inoculation with $B$. subtilis L2 significantly increased plant height by 16,20 and $18 \%$ compared to control at 4,8 and 12 WAP. At 8 and 12 WAP, leaf length significantly raised by B. subtilis L2 as compared to uninoculated control. B. subtilis L2 significantly increased the number of leaves per plant and leaf width by 30 and $21 \%$ respectively when comparing with non-inoculated plants at 8 WAP. The percentage increase in chlorophyll content resulted from the inoculation with B. subtilis L2 over the control was $10.5 \%, 15.5 \%$ and $18.4 \%$ at 4,8 and 12 WAP respectively. It is concluded that there is a significant positive effect of inoculation with B. subtilis L2 on the growth of ginger. B. subtilis L2 strain can be used as a potential agent or bio-fertiliser for stimulation of ginger growth.

\section{Introduction}

Ginger (Zingiber officinale Roscoe) is a spice and medicinal plant belonging to the family Zingiberaceae family. Ginger has been utilised in folk medicine in India and China. Especially in India, the fresh and dry root of ginger is widely used in medicine, food industry and also as a vegetable. It is used to make gingerbread, sweets, cakes and snacks in western countries. It has been long time utilised in folk medicine as a drug considering colds, sore throats, coughs, asthma and arthritis (1-5).

Ginger is rich in beneficial minerals such as phosphorus, potassium and calcium which play an important role in human physiological processes.
These substances play an essential role in boosting human immunity and maintaining good health. Ginger root contains biologically active compounds. It also contains carbohydrates (6), fats (7), proteins, vitamins (8) and minerals (9), organic acids (10), amino acids (11), monoterpenoids (camphene, cineole, borneol, citral, curcumin and linalol) and gingerol (1214).

Crop cultivation and disease control can be achieved through the use of chemical fertilisers and pesticides; their long-term use has a damaging effect on plant ecology (15). Consequently, plant growthpromoting bacteria (PGPR) have been used to improve soil fertility, plant development and plant health (1618). PGPR play a leading part in improving plant

(C) Jabborova et al (2021). This is an open-access article distributed under the terms of the Creative Commons Attribution License, which permits unrestricted use, distribution and reproduction in any medium, provided the original author and source are credited (https://creativecommons.org/licenses/by/4.0/)

To cite this article: Jabborova D, Enakiev Y, Sulaymanov K, Kadirova D, Ali A, Annapurna K. Plant growth promoting bacteria Bacillus subtilis promote growth and physiological parameters of Zingiber officinale . Plant Science Today. 2021;8(1):66-71. https://doi.org/10.14719/pst.2021.8.1.997 
growth through a variety of mechanisms. They can contribute to plant growth includes nitrogen uptake, synthesis of phytohormones, minerals solubilisation, siderophore production, inhibition of plant ethylene synthesis, production of antibiotics and the production of enzymes (19-26). These rhizobacteria have been found to improve plant growth (27-35). Notably, representatives of the $B$. subtilis are recognised for their helpful action on the growth of plants (36). The inoculation with Bacillus sp. increased the plant tolerant to stress and produces various plant hormones for development enhancement (37). The ability of Bacillus subtilis PTS394 strain increased tomato (Solanum lycopersicum) height and root growth (38). We conducted the present study to determine the impact of plant growth-promoting Bacillus subtilis on growth, transpiration rate and chlorophyll content of ginger.

\section{Materials and Methods}

\section{Bacterial strain}

Bacillus subtilis L2 strain were obtained from the Laboratory of Medicinal Plants Genetics and Biotechnology, Institute of Genetics and Plant Experimental Biology. B. subtilis L2 was cultured using nutrient agar containing beef extract $3 \mathrm{gm}$, peptone $5 \mathrm{gm}$, agar $15 \mathrm{gm}$, water $1000 \mathrm{ml}$. Nutrient broth containing beef extract $3 \mathrm{gm}$, peptone $5 \mathrm{gm}$, water $1000 \mathrm{ml}$ was used for the rhizome inoculations.

\section{Phosphate solubilisation}

Phosphate solubilisation by bacteria phosphate solubilising ability was detected by spot inoculating pure isolated bacterial strain on the Pikovskaya medium contained $\mathrm{l}^{-1}$ : glucose, $10 \mathrm{gm} ; \mathrm{Ca}_{3}\left(\mathrm{PO}_{4}\right)_{2}$, 5 gm; $\left(\mathrm{NH}_{4}\right)_{2} \mathrm{SO}_{4}, 0.5$ gm; NaCl, 0.2 gm; $\mathrm{MgSO} 4.7 \mathrm{H}_{2} \mathrm{O}, 0.1 \mathrm{gm}$; $\mathrm{KCl}, 0.2$ gm; beef extract, 0.5 gm; $\mathrm{MnSO}_{4} . \mathrm{H}_{2} \mathrm{O}, 0.002$ gm; and $\mathrm{FeSO}_{4} .7 \mathrm{H}_{2} \mathrm{O}, 0.002$ gm (39) and incubated at $28{ }^{\circ} \mathrm{C}$ for three to seven days along with the control plates. The uninoculated plates served as control. All the inoculations were done in triplicate. Phosphate solubilisation by bacterial strain was tested by their ability to solubilise inorganic phosphate. After seven days the formation of clearing zones was evaluated.

\section{Indole acetic acid (IAA) production}

The strain was grown for $48 \mathrm{hr}$ on their respective media at 28. The fully grown strain was centrifuged at $3000 \mathrm{rpm}$ for $30 \mathrm{~min}$. The supernatant $(2 \mathrm{ml})$ was mixed with two drops of orthophosphoric acid and 4 $\mathrm{ml}$ of the Salkowski reagent $(50 \mathrm{ml}, 35 \%$ of perchloric acid, $1 \mathrm{ml} 0.5 \mathrm{M} \mathrm{FeCl}_{3}$ solution). The development of a pink colour indicated IAA production (40).

\section{Siderophore production}

The strain was spotted on the Chrome azurol S agar media components are as follows: $100 \mathrm{mM}$ Pipes, 18 $\mathrm{mM} \mathrm{NH}{ }_{4} \mathrm{Cl}, 22 \mathrm{mM} \mathrm{KH}_{2} \mathrm{PO}_{4}, 2 \%$ (wt/vol) $\mathrm{NaCl}, 0.3 \%$ casamino acids, $0.2 \%$ (wt/vol) glucose, $10 \mu \mathrm{M} \mathrm{FeCl}_{3}, 58$ $\mu \mathrm{M}$ CAS and $80 \mu \mathrm{M}$ HDTMA (41). The strain was incubated at $28^{\circ} \mathrm{C}$ for $5-7$ days (41). The development of yellow-orange hallow zone around the bacterial spot has been considered as a positive indication for siderophore production.

\section{Greenhouse experiment}

Ginger rhizomes were used for plant growth pot experiments. Bacillus subtilis L2 strain were used for inoculation of the sterilised rhizome. One ml of each culture was pelleted by centrifugation, and cell pellets washed with $1 \mathrm{ml}$ phosphate-buffered saline (PBS; $20 \mathrm{mM}$ sodium phosphate, $150 \mathrm{mM} \mathrm{NaCl}, \mathrm{pH}$ 7.4) and resuspended into PBS. The suspensions used for the inoculation was adjusted to the final concentration of approximately $10^{7}$ cells $/ \mathrm{ml}$. Rhizomes were cultivated into plastic pots of soil. Soil samples were collected from the field of the Institute of Genetics and Plant Experimental Biology. For planting, small shallow pits were made and the rhizomes of $20 \mathrm{gm}$ each of ginger were placed in the pits. The rhizomes were placed $4 \mathrm{~cm}$ deep in the pits and the soil pressed over it. Plants were grown for 12 weeks in greenhouse conditions. After four, eight and twelve weeks, plant height, the number of leaves per plant, the length of leaf, the width of leaf, chlorophyll content and transpiration rate were determined. The fresh tissues from leaf were ground in a mortar and pestle containing $80 \%$ acetone for chlorophyll content. The optical density (O.D.) of the solution was read at 663-645 $\mathrm{nm}$ using a spectrophotometer. The chlorophyll content present in the extract $\left(\mathrm{mg} \mathrm{g}^{-1}\right.$ tissue) was calculated by using the following calculation (42):

Total chlorophyll content $=20.2 x O \cdot D \cdot 645+18.2$ O.D.633

\section{Statistical analysis}

Experimental data were analysed with the StatView Software using ANOVA. The significance of the effect of treatment was determined by the magnitude of the F value $(\mathrm{P}<0.05)$.

\section{Results and Discussion}

The results illustrated in Table 1 shows plant growthpromoting characteristics of Bacillus subtilis L2 strain. Further B. subtilis produced siderophore, IAA and caused P-solubilization. (Table 1). In the present investigation, $B$. subtilis L2 has shown positive results for plant growth-promoting characteristics such as IAA, phosphate solubilisation and siderophore production

Table 1. Plant growth-promoting characteristics of $B$. subtilis L2 strain

\begin{tabular}{lcc}
\hline Strain & IAA & $\begin{array}{l}\text { Phosphate } \\
\text { solubilisation }\end{array}$ \\
\hline B. subtilis L2 + & + \\
\hline + Positive for the test;- Negative for the test
\end{tabular}

The results also showed that at 8 and 12 weeks after planting (WAP), the bacterial inoculation increased the height of the plant. The maximum plant height was observed at 12 WAP (Fig. 1a). Plant height increased notably by $53 \%$ at 8 WAP compared to 4 WAP. Ginger plant height peaked at 12 weeks compared to 4 and 8 WAP of inoculation. The height of the plant significantly increased by $37 \%$ and $112 \%$ compared to control at 4 and 8 WAP. Interestingly, bacterial inoculation increased plant height at 4,8 


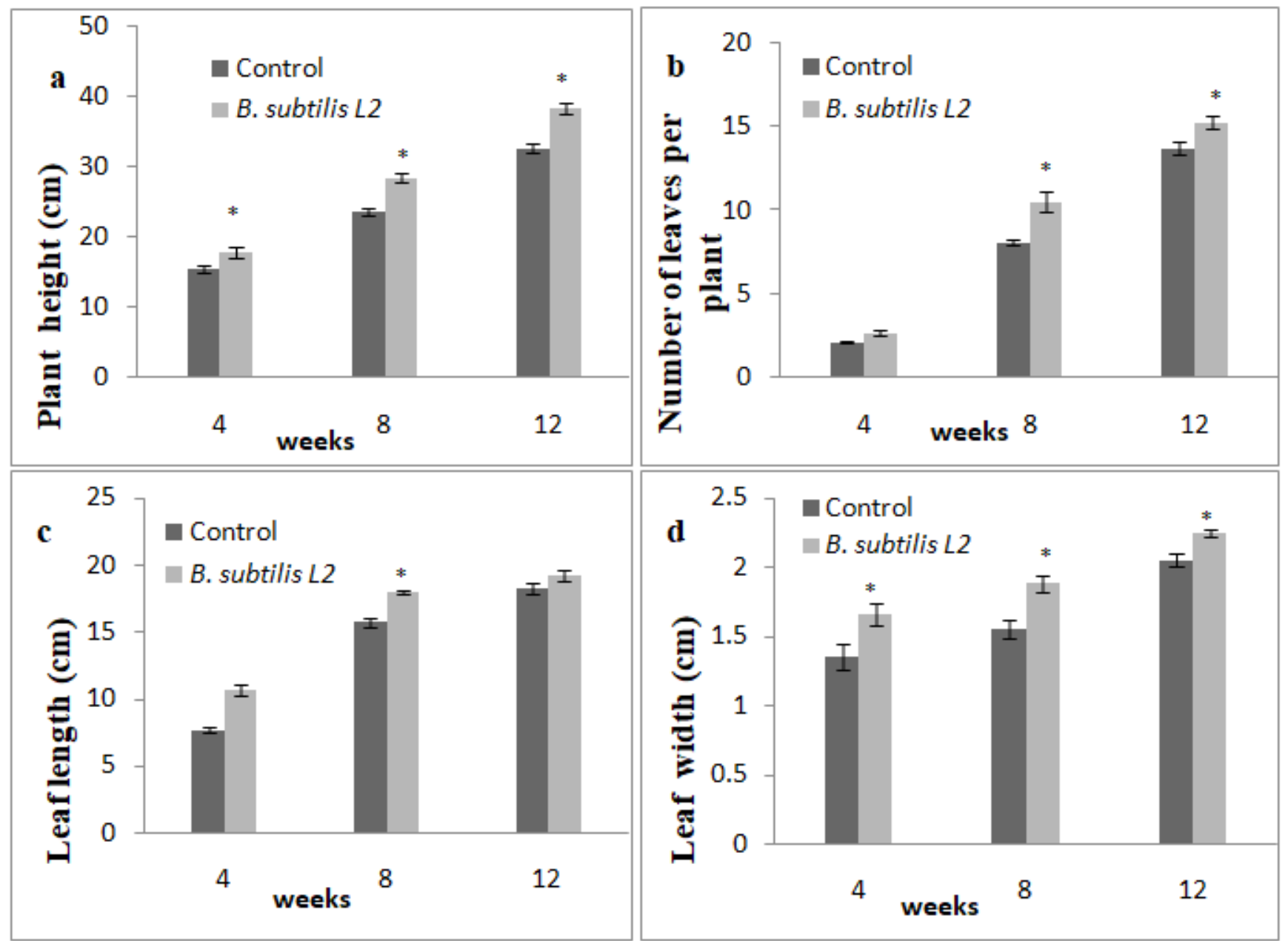

Fig. 1. Effect of inoculation with Bacillus subtilis L2 on plant height (a), number of leaves per plant (b), leaf length (c) and leaf width (d) of Ginger (Zingiber officinale).

and 12 WAP. Inoculation with $B$. subtilis L2 significantly increased plant height by 16, 20 and $17 \%$ compared to control at 4, 8 and 12 WAP.

The number of leaves per plant at 12 WAP is best and significantly different with 4 WAP and 8 WAP (Fig. 1b). At 12 WAP, the number of leaves significantly raised by $69 \%$ than uninoculated control. Comparatively a smaller number of leaves at four weeks confirmed that the total leaf number peaked at eighth and twelfth weeks. B. subtilis L2 significantly increased the number of leaves per plant by 29 and $10 \%$ respectively when comparing with non-inoculated plants at 8 and 12 WAP.

The length of leaves per plant at 12 WAP is best and significantly different with 4 and 8 WAP (Fig. 1c). The leaf length significantly increased by $139 \%$ and $16 \%$ compared to control at 4 and 8 WAP. Bacterial inoculation improved leaf length at 4, 8 and 12 WAP. Inoculation with $B$. subtilis L2 significantly enhanced leaf length by 39 and 14\% comparing with uninoculated plants at 4 and 8 WAP.

The leaf width sharply increased during 4, 8 and 12 weeks in both uninoculated and inoculated conditions. The leaf width peaked at 12 WAP compared to uninoculated control 4 and 8 WAP (Fig. 1d). Inoculation with $B$. subtilis L2 significantly increased the leaf width at 4,8 and 12 WAP. $B$. subtilis L2 enhanced the leaf width significantly by $22 \%, 215$ and $9 \%$ compared to control uninoculated at 4, 8 and 12 WAP.
Regarding the effect of $B$. subtilis L2, it was noted that $B$. subtilis L2 treatment increased the transpiration rate significantly over the control at 4, 8 and 12 WAP. The transpiration rate gradually increased during 4 WAP control treatment. B. subtilis L2 treatment showed an increase of $8.6 \%, 9.8 \%$ and $10.0 \%$ over the control at 4,8 and 12 WAP respectively (Fig. 2a).

The inoculation of Bacillus subtilis L2 improved the chlorophyll content compared to the control at 8 and 12 WAP (Fig. 2b). Inoculation with $B$. subtilis L2 also increased slightly the chlorophyll content at 4 WAP. The percentage increase in chlorophyll content resulted from the inoculated with $B$. subtilis L2 over the control was $10.5 \%, 15.5 \%$ and $18.4 \%$ at 4,8 and 12 WAP respectively.

\section{Discussion}

Plant growth-promoting bacteria (PGPR) established to mass-produce a wide diversity of plant-helpful metabolites such as IAA, siderophore and $P$ solubilisation that support in plant growth and the portly energy of the plant (28-31). Mass-production of IAA (Indole-3-acetic acid), siderophore and $P$ solubilisation have been informed in numerous species of Bacillus, Pseudomonas and Bradyrhizobium including $B$. japonicum (24), B. subtilis (18) and $P$. putida $(38,43-45)$. In the present investigation, $B$. 


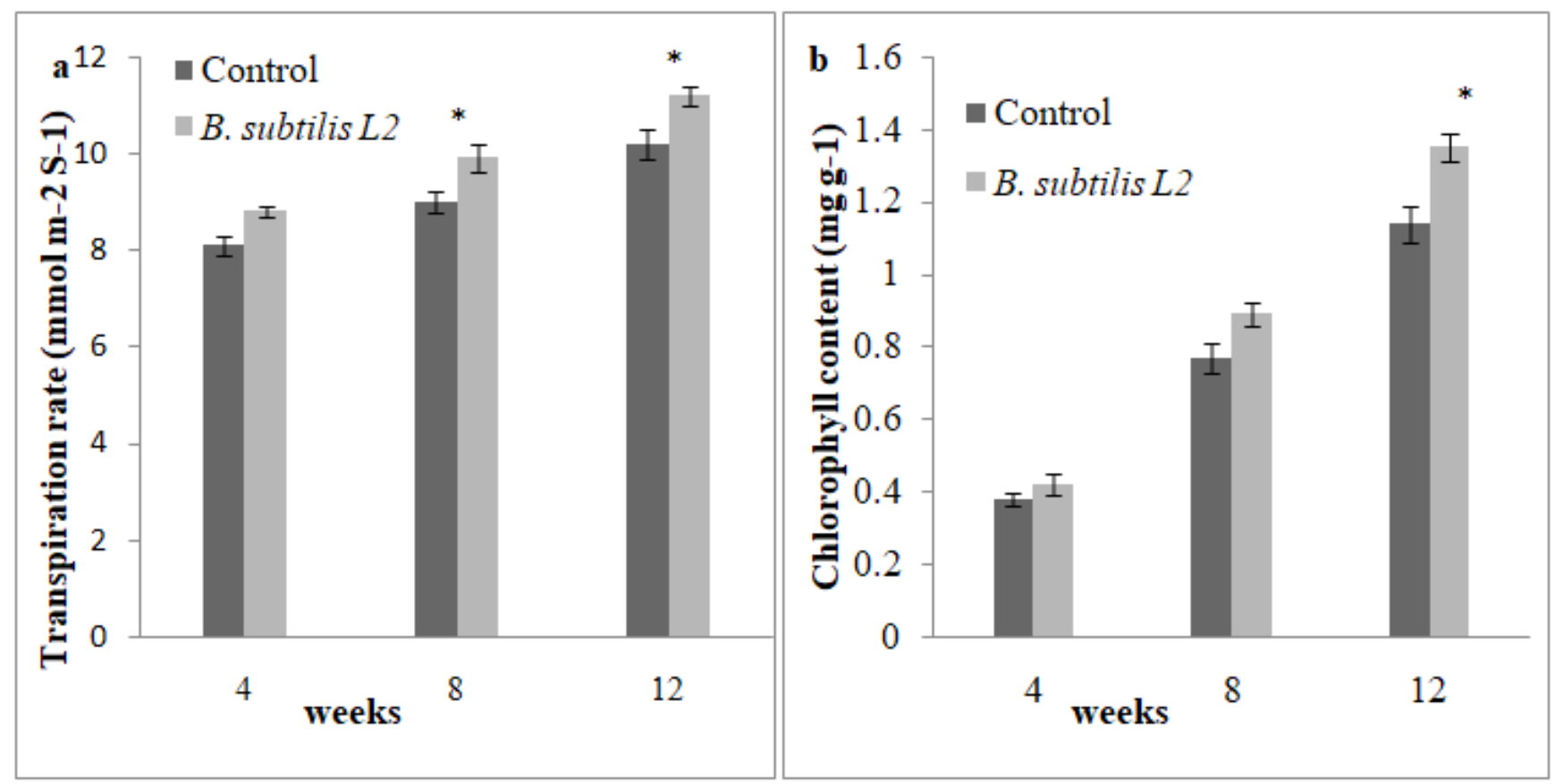

Fig. 2. Effect of inoculation with B. subtilis L2 on transpiration rate (a) and chlorophyll content (b) of Ginger (Zingiber officinale).

subtilis L2 has shown significant results for plant growth-promoting characteristics such as IAA, phosphate solubilisation and siderophore production (Table 1). Several researchers (46) reported the production of siderophore and phytohormones such as IAA and gibberellins in Pseudomonas sp., Rhizobium sp. and Azotobacter sp. isolated from the sugarcane field rhizosphere. The production of phytohormones, enzymes antagonistic activity in endophytic PGPR strains (47). Some authors (19) recorded the production of the rich quantity of siderophore in $P$. fluorescence NCIM 5096 and $P$. putida NCIM2847.

Our results showed that at 8 and 12 weeks after planting (WAP) inoculation with $B$. subtilis L2 significantly improved height of the plant, length of leaf and the number of leaves per plant and leaf width of ginger compared to control. There are many studies which showed that inoculation with rhizobacteria increases the plant, height, plant biomass and plant growth of legume crops (18, 28, 33, 43 , 44). Inoculation with $B$. subtilis PTS-394 increased plant growth of tomato compared to control (38). In a study it was confirmed that the inoculation of effective $B$. japonicum strain significantly increased the plant growth of soybean (27).

The results showed that decrease of leaf transpiration and chlorophyll content as compared to the control at 4 WAP, respectively (Fig. 2a, b). Uninoculated control, the transpiration rate and the chlorophyll content are primarily reduced at 4 WAP. There are reports stating that control (at 180 days after planting) increase chlorophyll content compared to 120 days after planting (48). The results of this study indicated that the inoculation of $B$. subtilis L2 in the ginger plant could influence the transpiration rate and the chlorophyll content at 8 and 12 WAP. Similarly, promotion in plant growth promoting rhizobacteria has been reported improving transpiration and chlorophyll content in mungbean (49). Plant growth-promoting rhizobacteria inoculation increased chlorophyll content in legume crops such as mungbean, pea and soybean (49-51).

\section{Conclusion}

Bacilus subtilis had a significantly positive impact on plant growth, transpiration rate and chlorophyll content of ginger (Zingiber officinale). At 12 weeks after planting has substantial plant growth indicated by the significantly increased plant growth parameters, transpiration rate and chlorophyll content. Inoculation with $B$. subtilis $\mathrm{L} 2$ enhanced plant height, leaf number, leaf length, transpiration leaf and chlorophyll content. It is concluded that there is a significant and positive effect of inoculation with $B$. subtilis L2 on growth and physiological properties of ginger. Inoculation of $B$. subtilis could play an important role in sustainable agriculture by improving plant growth and productivity besides playing important role in P-solubilization, IAA (Indole-3-acetic acid) and siderophore production. $B$. subtilis L2 strain can be used as a potential agent or biofertiliser for stimulation of ginger growth and yield.

\section{Acknowledgements}

The authors extend their appreciation to the Ministry of Innovational Development of the Republic of Uzbekistan and the Department of Biotechnology, Government of India (DBT) and TWAS.

\section{Authors' contributions}

DJ designed the experiments and wrote the manuscript. KA and AA interpreted the data and corrected the manuscript. YE performed analysis. KS and DK performed the methodology. All authors have read and approved the paper. 


\section{Conflict of interests}

Authors do not have any conflict of interest to declare.

\section{References}

1. Ebadi M. Pharmacodynamics basis of herbal medicine. 2nd ed. Boca Raton: Taylor and Francis Group; 2006 https://doi.org/10.1201/9781420006452

2. Khare CP. Indian Medicinal Plants: An Illustrated Dictionary. Springer-Verlag New York; 2007.

3. Banerjee S, Mullick HI, Banerjee J, Ghosh A. Zingiber officinale: 'A natural gold'. Int J Pharmaceutical Bio-Sci. 2011;2:283-94.

4. Duke JA. Handbook of Medicinal Herbs. Boca Raton: CRC press; 2002. https://doi.org/10.1201/9781420040463

5. Grzanna R, Lindmark L, Frondoza CG. Ginger - a herbal medicinal product with broad anti-inflammatory actions. Journal of Medicinal Food. 2005;8(2):125-32. https://doi.org/ 10.1089/jmf.2005.8.125

6. Zadeh JB, Kor NM. Physiological and pharmaceutical effects of Ginger (Zingiber officinale Roscoe) as a valuable medicinal plant. European Journal of Experimental Biology. 2014;4(1):8790

7. Al-Amin ZM, Thomson M, Al-Qattan KK, Peltonen-Shalaby R, Ali M. Anti-diabetic and hypolipidaemic properties of ginger (Zingiber officinale) in streptozotocin-induced diabetic rats. British Journal of Nutrition. 2006;96(4):660-66. https://doi.org/ 10.1079/bjn20061849

8. Andlauer W, Fürst P. Nutraceuticals: a piece of history, present status and outlook. Food Research International. 2002;35(23):171-86

9. Liu Y, Liu J, Zhang Y. Research Progress on Chemical Constituents of Zingiber officinale Roscoe. BioMed Research International. 2019. https://doi.org/10.1155/2019/5370823

10. Shuhua L. Contents of nitrate, nitrite, vitamin C, organic acid and total sugar of Zingiber officinale in plastic greenhouse. Journal of Anhui Agricultural Sciences. 2006;34(14):33-46.

11. Zhang YF, Ma ZC. Ingredients and applications of ginger. Chemistry Teaching, 2012;8:73-80.

12. Asnani VE, Verma RJ. Antioxidative effect of rhizome of Zingiber officinale on paraben induced lipid peroxidation: an in-vitro study. Acta Pol Pharm. 2007;64(1):35-37.

13. Prasad S, Tyagi AK. Ginger and its constituents: role in prevention and treatment of gastrointestinal cancer. Gastroenterology Research and Practice. 2015 Jan 1. https://doi.org/10.1155/2015/142979.

14. Zhang F, Ma N, Gao YF, Sun LL, Zhang JG. Therapeutic effects of 6-gingerol, 8-gingerol and 10-gingerol on dextran sulfate sodium-induced acute ulcerative colitis in rats. Phytotherapy Research. 2017;31(9):1427-32. https://doi.org/10.1002/ptr.5871

15. Yadav IC, Devi NL, Syed JH, Cheng Z, Li J, Zhang G, Jones KC. Current status of persistent organic pesticides residues in air, water and soil, and their possible effect on neighbouring countries: a comprehensive review of India. Science of the Total Environment. 2015;511:123-37. https://doi.org/ 10.1016/j.scitotenv.2014.12.041

16. Elkoca E, Kantar F, Sahin F. Influence of nitrogen fixing and phosphorus solubilising bacteria on the nodulation, plant growth and yield of chickpea. Journal of Plant Nutrition. 2006; 31(1):157-71. https://doi.org/10.1080/01904160701742097

17. Sayyed RZ, Patel PR, Shaikh SS. Plant growth promotion and root colonisation by EPS producing Enterobacter sp. RZS5 under heavy metal contaminated soil. Indian Journal of Experimental Biology. 2015;53:116-23.

18. Jabborova D, Wirth S, Kannepalli A, Narimanov A, Desouky S, Davranov K, Sayyed RZ, El Enshasy H, Malek RA, Syed A, Bahkali AH. Co-Inoculation of Rhizobacteria and Biochar Application Improves Growth and Nutrientsin Soybean and Enriches Soil Nutrients and Enzymes. Agronomy. 2020;10(8):1142.https://doi.org/10.3390/agronomy10081142
19. Sayyed RZ, Badgujar MD, Sonawane HM, Mhaske MM, Chincholkar SB. Production of microbial iron chelators (siderophores) by fluorescent Pseudomonads. Indian Journa of Biotechnology. 2005;4:484-90.

20. Mohamed HI, Gomaa EZ. Effect of plant growth promoting Bacillus subtilis and Pseudomonas fluorescens on growth and pigment composition of radish plants (Raphanus sativus) under NaCl stress. Photosynthetica. 2012;50(2):263-72. https://doi.org/ 10.1007/s11099-012-0032-8

21. Glick BR. Bacteria with ACC deaminase can promote plant growth and help to feed the world. Microbiological Research 2014;169:30-39. http://dx.doi.org/10.1016/j.micres.2013.09.009

22. Egamberdieva D, Jabborova D. Efficiency of phytohormoneproducing Pseudomonas to improve salt stress tolerance in Jew's Mallow (Corchorus olitorius L.). Plant-growth-promoting Rhizobacteria (PGPR) and Medicinal Plants Springer International Publishing Switzerland. 2015;201-13 https://doi.org/_10.1007/978-3-319-13401-7_9

23. Egamberdieva D, Jabborova D, Hashem A. Pseudomonas induces salinity tolerance in cotton (Gossypium hirsutum) and resistance to Fusarium root rot through the modulation of indole-3-acetic acid. Saudi Journal of Biological Sciences. 2015;22(6):773-79. https://doi.org/10.1016/j.sjbs.2015.04.019

24. Jabborova DP, Narimanov AA, Enakiev YI, Davranov KD. Effect of Bacillus subtilis 1 strain on the growth and development of wheat (Triticum aestivum L.) under saline condition. Bulgarian Journal of Agricultural Science. 2020;26(4):744-47.

25. Jabborova D, Davranov K. Effect of phosphorus and nitrogen concentrations on root colonisation of Soybean (Glycine max L.) by Bradyrhizobium japonicum and Pseudomonas putida. International Journal of Advanced Biotechnology and Research (IJBR), 2015;6:418.

26. Sagar A, Sayyed RZ, Ramteke PW, Sharma S, Marraiki N, Elgorban AM, Syed A. ACC deaminase and antioxidant enzymes producing halophilic Enterobacter sp. PR14 promotes the growth of rice and millets under salinity stress. Physiology and Molecular Biology of Plants. 2020;26(9):1847-54 https://doi.org/10.1007/s12298-020-00852-9

27. Masciarelli O, Llanes A, Luna V. A new PGPR co-inoculated with Bradyrhizobium japonicum enhances soybean nodulation Microbiological Research. 2014;169(7-8):609-15. https://doi.org/ 10.1016/j.micres.2013.10.001

28. Egamberdieva D, Wirth S, Jabborova D, Räsänen LA, Liao H. Coordination between Bradyrhizobium and Pseudomonas alleviates salt stress in soybean through altering root system architecture. Journal of Plant Interactions. 2017;12(1):100-07. https://doi.org/10.1080/17429145.2017.1294212

29. Egamberdieva D, Jabborova D, Berg G. Synergistic interactions between Bradyrhizobium japonicum and the endophyte Stenotrophomonas rhizophila and their effects on growth and nodulation of soybean under salt stress. Plant and Soil. 2016;405(1-2):35-45.

30. Egamberdieva D, Jabborova D, Wirth SJ, Alam P, Alyemeni MN, Ahmad P. Interactive effects of nutrients and Bradyrhizobium japonicum on the growth and root architecture of soybean (Glycine $\max$ L.). Frontiers in Microbiology. 2018;9:1000 https://doi.org/10.3389/fmicb.2018.01000

31. Jabborova DP, Enakiev YI, Davranov KD, Begmatov SA. Effect of co-inoculation with Bradyrhizobium japonicum and Pseudomonas putida on root morph-architecture traits, nodulation and growth of soybean in response to phosphorus supply under hydroponic conditions. Bulgarian Journal of Agricultural Science. 2018;24(6):1004-11

32. Kashem MA, Mian MH and Rahman MF. Effect of Bradyrhizobium on the yield of mungbean (Vigna radiata L.) grown in Ganges Tidal floodplain soil. Journal of Agricultural Research. 2000;33(38):407.

33. Raza W, Akhtar MJ, Arshad M, Yousaf S. Growth, nodulation and yield of mungbean (Vigna radiata L.) as influenced by coinoculation with rhizobium and plant growth promoting rhizobacteria. Pakistan Journal of Agricultural Sciences. 2004;41(3/4):125

34. Dinesh R, Anandaraj M, Kumar A, Srinivasan V, Bini YK., Subila KP, Aravind R, Hamza S. Effects of plant growth- 
promoting rhizobacteria and NPK fertilizers on biochemical and microbial properties of soils under ginger (Zingiber officinale) cultivation. Agricultural Research Volume. 2013;2:346-53. https://doi.org/10.1007/s40003-013-0080-8

35. Kumar A, Vandana, Singh M, Singh PP, Singh SK, Singh PK Pandey KD. Isolation of plant growth promoting rhizobacteria and their impact on growth and curcumin content in Curcuma longa L. Biocatalysis and Agricultural Biotechnology. 2016;8:17. https://doi.org/10.1016/j.bcab.2016.07.002

36. Fritze D. Taxonomy of the genus Bacillus and related genera: the aerobic endospore-forming bacteria. Phytopathology. 2004;94(11):1245-48 https://doi.org/10.1094/PHYTO.2004.94.11.1245

37. Patel S, Jinal HN, Amaresan N. Isolation and characterisation of drought resistance bacteria for plant growth promoting properties and their effect on chilli (Capsicum annuum) seedling under salt stress. Biocatalysis and Agricultural Biotechnology. https://doi.org/10.1016/j.bcab.2017.09.002 2017;12:85-89.

38. Qiao J, Yu X, Liang X, Liu Y, Borriss R, Liu Y. Addition of plantgrowth-promoting Bacillus subtilis PTS-394 on tomato rhizosphere has no durable impact on composition of root microbiome. BMC microbiology. 2017;17(1):131. https://doi.org/ 10.1186/s12866-017-1039-x

39. Pikovskaya RI. Mobilisation of phosphorus in soil in connection with vital activity of some microbial species. Mikrobiologiya. 1948;17:362-70.

40. Bric JM, Bostock RM, Silverstone SE. Rapid in-situ assay for indoleacetic acid production by bacteria immobilised on a nitrocellulose membrane. Applied and Environmental Microbiology. https://doi.org/10.1128/AEM.57.2.535-538.1991

41. Patel PR, Shaikh SS, Sayyed RZ. Modified chrome azurol S method for detection and estimation of siderophores having affinity for metal ions other than iron. Environmental Sustainability. 2018;1(1):81-87. https://doi.org/10.1007/s42398 018-0005-3

42. Khan F, Asif M, Khan A, Tariq M, Ansari T, Shariq M, Siddiqui MA. Evaluation of the nematicidal potential of some botanicals against root-knot nematode, Meloidogyne incognita infected carrot: In-vitro and greenhouse study. Current Plant Biology. 2019;20:1001152. https://doi.org/10.1016/j.cpb.2019.100115

43. Egamberdieva D, Jabborova D. Improvement of cotton production in arid saline soils by beneficial microbes. In Crop
Yields: Production, Management Practices and Impact of Climate Change. 2013;109-22.

44. Egamberdieva D, Jabborova D, Wirth S. Alleviation of salt stress in legumes by co-inoculation with Pseudomonas and Rhizobium. In: Plant Microbe Symbiosis: Fundamentals and Advances. New Delhi: Springer. 2013;291-303.

45. Meliani A, Bensoltane A, Benidire L, Oufdou K. Plant growthpromotion and IAA secretion with Pseudomonas fluorescens and Pseudomonas putida. Research \& Reviews: Journal of Botanical Sciences. 2017;6(2):16-24.

46. Pandya ND, Desai PV, Sayyed RZ. Antifungal and phytohormone production ability of plant growth promoting rhizobacteria associated with the rhizosphere of sugarcane. World Journal of Microbiology and Biotechnology. 2011;13(1):112-16

47. Jabborova D, Annapurna K, Fayzullaeva M, Sulaymonov K Kadirova D, Jabbarov Z, Sayyed R. Isolation and characterisation of endophytic bacteria from ginger (Zingiber officinale Rosc.). Annals of Phytomed. 2020;9:116-21.

48. Singh M, Khan MM, Naeem M. Effect of nitrogen on growth, nutrient assimilation, essential oil content, yield and quality attributes in Zingiber officinale Rosc. Journal of the Saudi Society of Agricultural Sciences. 2016;15(2):171-78. https://doi.org/10.1016/j.jssas.2014.11.002

49. Ahmad M, Zahir ZA, Khalid M, Nazli F, Arshad M. Efficacy of Rhizobium and Pseudomonas strains to improve physiology, ionic balance and quality of mung bean under salt-affected conditions on farmer's fields. Plant Physiology and Biochemistry. $2013 \quad$ Feb 1;63:170-76 https://doi.org/10.1016/j.plaphy.2012.11.024

50. Barnawal D, Bharti N, Maji D, Chanotiya CS, Kalra A. ACC deaminase-containing Arthrobacter protophormiae induces $\mathrm{NaCl}$ stress tolerance through reduced ACC oxidase activity and ethylene production resulting in improved nodulation and mycorrhisation in Pisum sativum. Journal of Plant Physiology. 2014;171(11):884-94. https://doi.org/10.1016/j.jplph.2014.03.007

51. Kang SM, Radhakrishnan R, Khan AL, Kim MJ, Park JM, Kim BR, Shin DH, Lee IJ. Gibberellin secreting Rhizobacterium, Pseudomonas putida H-2-3 modulates the hormonal and stress physiology of soybean to improve the plant growth under saline and drought conditions. Plant Physiology and Biochemistry 2014;84:115-24. https://doi.org/10.1016/ 